\title{
Paul Klee, Um Artista Esclerodérmico
}

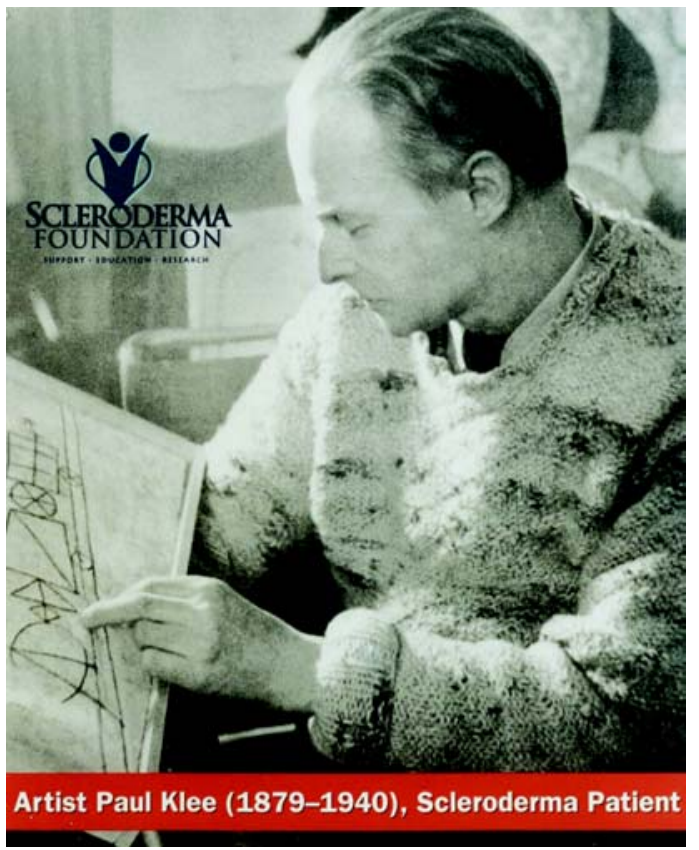

Figura 1 - Artista Paul Klee (1879-1940).
A arte é um reflexo do estado de espírito do artista, e muitas vezes demonstra também seu estado fisico, refletindo a atividade das doenças sistêmicas que o acometem. O artista Paul Klee (1879-1940), considerado um dos pioneiros da Arte Moderna no século XX, vem sendo tema da campanha de divulgação da "esclerose sistêmica" da Scleroderma Foundation desde 2000 (Figura 1).

$\mathrm{O}$ artista de espírito inquieto, com traços finamente elaborados e coloridos, pode ser observado no quadro Rotes Villenquartier (Subúrbio Vermelho), de 1920 (Figura 2), quando iniciava sua participação no movimento Bauhaus. Sua doença iniciou-se junto com a expansão do nazismo na Alemanha; vários de seus trabalhos foram apresentados na exibição Entartete Kunst (Arte Degenerada), na qual os nazistas procuraram denegrir a Arte Moderna.

Obrigado a exilar-se na Suíça, evoluiu com garra esclerodérmica, múltiplas úlceras isquêmicas, disfagia (no final da vida, usava somente dieta líquida) e fibrose pulmonar. Após ser acometido pela esclerose sistêmica, Klee evoluiu para um traçado com formas mais simplificadas, como pode ser observado em Fast Getroffen (Nearly Hit) (Figura 3); no entanto, apesar das significativas limitações fisicas em seus últimos anos de vida, suas obras conseguiram expressar seus sentimentos sobre a morte e a guerra, refletindo a miséria e o desespero. Durante a Reunião Anual do Colégio Americano de Reumatologia de 2001, em San Francisco, houve uma pequena exposição das obras de Paul Klee no San Francisco Museum of Modern Art.

PERCIVAL D. SAMPAIO-BARROS JOÃO FRANCISCO MARQUES NETO

Disciplina de Reumatologia

FIGURA 2 - ROTES

VILLENQUARTIER (SUBÚRBIO VeRMELHO), DE 1920.
Figura 3 - FAst Getroffen (NEARLY HIT).

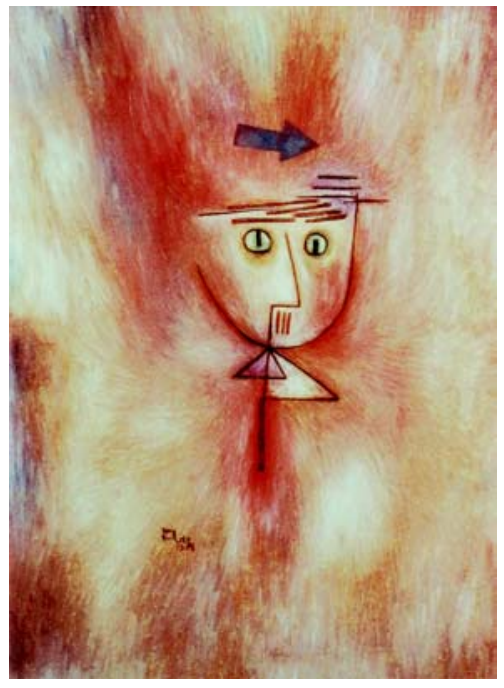

